\title{
CUERPO, ESCRITURA Y BIOPODER EN VACA SAGRADA, DE DIAMELA ELTIT
}

\author{
Kemy Oyarzún \\ Universidad de Chile, Santiago de Chile, Chile \\ koyarzun@gmail.com
}

\section{RESUMEN / ABSTRACT}

Las comunidades imaginarias inscriben el cuerpo en determinadas posibilidades semióticas y semánticas, en el seno de relaciones de poder que se expresan material y simbólicamente. Desplegar literariamente el cuerpo fragmentado de lo existente implica simbolizar una subjetividad encarnada en el propio proceso de creación verbal. En este artículo, estudiamos el registro imaginario y la simbólica del cuerpo en Vaca Sagrada, novela de Diamela Eltit (1991, 132). Nuestra lectura explora la subjetividad encarnada en el cuerpo, no solo como problema literario de esta novela en particular, sino como escritura del cuerpo en situación de biopoder, al convertirse la propia vida material en objeto de sometimiento, particularmente desde la dictadura. Habitar cuerpo a cuerpo la ciudad letrada sin renunciar al potencial transformador de la letra encarnada, abarca aquí un aspecto central de la propuesta estética post dictatorial (Violi 1991) de Diamela Eltit.

PALABRAS Clave: cuerpo, biopoder, estética literaria, género.

\section{Body, WRITING AND BIOPOWER IN VACA SAgRAda by Diamela Eltit}

Imaginary communities inscribe the body in concrete semiotic and semantic possibilities, within a system of engendered power relations. In this article, we study the imaginary and symbolic bodily constructions in Vaca Sagrada, novel by Diamela Eltit. Our reading explores embodied subjectivity not only as a literary problem in the novel, but as biopower, a political situation whereby material life itself becomes a specific object of power since Chile's dictatorship in the 70's. The old, enlightened "lettered city" is subjected to the transformative potential of the "embodied letter", revealing a central aspect of Eltit's aesthetic post dictatorial vision.

KEYWORDS: body, biopower, literary esthetics, gender. 
"La generación actual se concibe y se percibe Antropófago. El Antropófago: nuestro creador, principio de todo"

António de Alcântara Machado 192.

\section{CUERPO VIVIDO. CUERPO VISTO}

Cada comunidad imaginaria inscribe el cuerpo en determinadas posibilidades semióticas y semánticas y tiene además sus formas específicas de significarlo. Los estudios feministas y cuir ponen en el debate ciudadanías corporeizadas ${ }^{1}$. Anteriormente, desde la fenomenología, la percepción irrumpía en el escenario. Merleau Ponty distinguió entre "cuerpo vivido" y "cuerpo visto", insistiendo que este último ha hegemonizado la cultura occidental, particularmente a partir del cogito cartesiano, "pienso, luego existo" (Merleau Ponty 1945). Se inaugura un nuevo desplazamiento: existo, percibo, veo, pienso $^{2}$. En consecuencia, podríamos insistir que, subordinada a la cultura occidental, la "ciudad letrada" latinoamericana también ha hecho pasar la existencia de lo diverso por la ilusión unitaria y excluyente de la mirada, una mirada racionalista, patriarcal y neocolonial. Vaca Sagrada se instala en el eje de la tensión cultural entre esa "ciudad letrada" (Rama 1984, 20) y una "ciudad encarnada" que emergía en los 80 y se ha acentuado con fuerza en la post dictadura a partir de movimientos sociales corporeizados. La relación entre uno y otro registros tiene que ver con la diferencia entre "cuerpo fragmentado, percibido" y "cuerpo simbolizado", entendiendo que esa simbolización

1 Lo queer o cuir refiere al movimiento por los derechos sexuales LGBTI (lésbicos, gay, bisexuales, trans, intersexuales). Implica la visibilización, el radicalismo político cultural contra leyes discriminatorias, y en especial, orgullo de la propia homosexualidad (Serrano 1998, 3); desestabilizar el binarismo que imponía e impone la heteronormatividad. Para Beatriz Preciado, se trata de nuevas formas de hacer política (Preciado, p. 13). América Latina se apropió del término Queer acuñado en Norteamérica para referirse a lo abyecto, a lo cuir; noción de género en desborde, capaz de provocar que las categorías identitarias no solo se ubiquen en la frontera sino hagan de ese un lugar de deleite y exceso, de modo que funciona como categoría de análisis para ciertas subjetividades contemporáneas, sobrepasando la nominación norteamericana.

Según Carlos Ossa: "la inauguración de un modo de organización visual del mundo que no tiene una concepción definida y estructurada, más bien, asume la ley mimética de la reproducción mecánica - propia del periodo- y la convierte en un sistema de veridicción, disciplina y estatus" (216). 
hace pasar como unitario y homogéneo el cuerpo pulsional. Más que el cuerpo visto, el cuerpo existente, plural y fragmentado deviene la instancia más porosa al movimiento y a la heterogeneidad. Metodológicamente, el presente estudio es deudor de los feminismos teóricos, cuir y de los estudios culturales latinoamericanos (Oyarzún 1996). La dimensión sexo-género como performativa es central a nuestra mirada, en la medida en que desencializa la diferencia binaria y la expone a desplazamientos que expresan nuevos y móviles agenciamientos, siempre incardinados, encarnados, transitorios (Olea 1993, Butler 1990).

Los retornos del cuerpo existente y fragmentado han sido persistentes en la cultura, sobre todo desde El Bosco al surrealismo, pero también en textos de los pueblos originarios, marginados de la mirada colonial, tales como el Popol Vuh o el Chilam Balam. Desplegar literariamente el cuerpo fragmentado de lo existente implica simbolizar una subjetividad encarnada en el tiempo y el territorio, proceso de creación perceptiva y verbal que Vaca Sagrada, novela que Diamela Eltit publicó al comienzo de la postdictadura (Eltit 1991, 132) pone en debate. La tesis que presento aquí refiere a que Diamela Eltit resignifica los modos de habitar cuerpo a cuerpo la ciudad letrada, sin renunciar al potencial de la letra incardinada o encarnada, abarca aquí un aspecto central de la propuesta estética de Diamela Eltit y los movimientos sexo-genéricos (Violi 1991) ${ }^{3}$. El sujeto encarna siempre en movimiento para desplazarse, móvil y performativo, en un proceso de fuerzas (afectos y desafectos) que se interceptan según variables de tiempo y espacio, históricas y territoriales. Para Michel Foucault esa encarnación no solo es un problema literario-cultural, sino biopolítico, al convertirse la propia vida material en objeto de poder a partir del siglo XVIII $(1986,818)$. En el caso de las dictaduras del Cono Sur, el cuerpo se experimenta en un vuelco materialista. Re-materializados con sentidos ético-políticos, estéticos, lo personal y cotidiano, así como los cuerpos mismos en sus actos de habla, dejan entrever las relaciones cotidianas de poder. El poder tatúa los cuerpos

\footnotetext{
Al preguntarse por las corrientes lingüísticas, los sujetos "sexualmente diferenciados" y las formas específicas de la dessubjetivación femenina, la lingüista Patricia Violi insiste en que el sujeto está encarnado, incardinado, aunque la lingüística tradicional no lo concibiese así (Violi 1991). Es el sujeto trascendental y esencialista el que aparece descorporeizado. En el caso chileno y latinoamericano debemos entender que esa descorporeización es efecto de neo/colonización.
} 
directamente; por ello la invisibilización de esos tatuajes -bien lo devela Vaca Sagrada-habrá de "doler" en la carne.

Para los dispositivos victorianos (de larga duración en Chile y América Latina), el blanqueo corporal ha afectado sobre todo el sexo en una era en que se disputan su laicidad, heterogeneidad y pluralismo. La dialéctica de la represión en la modernidad tiene como nudo más temido la concepción laica del cuerpo, incluida la familia ${ }^{4}$. Los feminismos han evidenciado esa tensión, desde proyectos de igualdad y diferencia, a partir del concepto de Sistema Sexo Género; rearticular sexualidades, culturas y ciudadanías es parte del pensamiento de diferencias equivalentes y no jerárquicas.

El sexo sigue expresado como no-laico, pasando de esa sacralización pre moderna a su fetichismo como mercancía. Ese sería el referente más profundo y condensado del término "sagrado" en el título de la novela que aquí nos ocupa. La protagonista narradora expresa el mandato hegemónico de tener que "borrar cualquier atisbo de carnalidad" (90), pese a que su cuerpo estaba "en estado de permanente demanda" (90). El ideologema predominante del sexo y la familia constituye en postdictadura una forma de "modernización conservadora" (Oyarzún 2000, 117) cuyas operaciones son dobles: a) mandato a callar y b) al mismo tiempo, interpelación a hacer hablar sobre el sexo. El mandato a decir "la verdad" del cuerpo allá abajo se cumple primero en el ámbito neoconfesional de lo psicológico cuando el cuerpo y la sexualidad se medicalizan y la novela psicológica se abre a la intriga del retorno formal del inconsciente. Vaca Sagrada expresa una revuelta ante los dos polos de ese ideologema (callar y hacer hablar), precisamente cuando se produce el estallido de la sexualidad como "vil y preciosa mercancía" (Rubin 1986, 107), en el hipercapitalismo post dictatorial'.

\footnotetext{
La familia es uno de los aparatos ideológicos aparentemente "íntimos" del Estado, y como tal sirve para dobles propósitos. En Chile el "familiocentrismo" o ideologema de la familia se acentúa en dictadura. Este ideologema moldea los sujetos en las "artes" y "artimañas" del vasallaje. Es el Estado "vuelto del revés". Caracterizamos como "modernización conservadora" el ideologema de la familia predominante en Chile (Oyarzún 2000).

Este ensayo constituye una mirada diacrítica sobre las más significativas visiones de la crítica existente. Me refiero a los aportes de Paula y Soledad Bianchi, Eugenia Brito, Rubí Carreño, Sandra Garabano, Juan Carlos. Lértora, Leonidas Morales, Jean Franco, Lucía Guerra, Jo Labanyi, María Inés Lagos, Bernardita Llanos, Luz Angela Martínez, Fernando Moreno, Cecilia Ojeda, Raquel Olea, Julio Ortega, Claudia Posadas, Marcela Prado, Cynthia Tompkins.
} 


\title{
CANIBALISMO, HITO PRIVILEGIADO DEL CUERPO NARRADO
}

\author{
“hacer vivir en sí mismo el cuerpo devorado". \\ Claude Fischler
}

Canibalismo, fiesta, sublevación de las trabajadoras sexuales, cuerpo picoteado, desengaño político, despertar hacia la soledad y proyecto escritural en abismo constituyen en esta lectura hitos significativos del ciclo textual. Por razones de espacio, nuestra lectura se centrará en el impacto del canibalismo, el trabajo sexual y escritural, el ojo picoteado y la fuga hacia la soledad como autoconocimiento estético.

El canibalismo es un hito clave de los desplazamientos del relato; se expresa cuando la protagonista descubre que su cuerpo empieza a traicionarla (90), tensionando la relación entre Yo y mundo, entre objeto y sujeto deseantes, entre lo abyecto y la cultura. A partir de allí, pero nunca en forma de encadenamiento causal, la protagonista sentirá asco hacia su cuerpo, repudio del placer sobre sí misma (127). Literalmente, el canibalismo como significante apunta al momento en que ella toma "un trozo de carne descompuesta" y empieza a comerla lentamente (90). Al mismo tiempo que su propio cuerpo la empieza a traicionar, ella siente que el cuerpo de Manuel, detenido en el sur, empieza a disolverse en su memoria (90), de modo que digerir o no lo acaecido en ese sur dictatorial expresa un punto álgido del relato. El acto de canibalismo (comer la carne descompuesta) refiere así a oralidad "no civilizada", pero también, en un gesto paródico, implica la "barbarie" del terrorismo de Estado, en la medida en que es allí que la relación entre cuerpo y cultura se "descompone". Ese canibalismo se convierte en bumerán narrativo, polo de repulsa y atracción para una enunciación que pulsa y pugna por la autonomía de la voz narradora. La descomposición del cuerpo de la memoria, cuerpo del objeto del deseo, se opone aquí al Yo de la protagonista y precipita una fuga de la relación erótica interrumpida por una acción que revela los resortes psico-políticos de la dictadura. El cuerpo consumido es ya un cuerpo abyecto, caído y torturado, que inaugura el desplome del sentido, fantasma que apunta literalmente fuera de sí. Diríamos entonces que a partir del canibalismo, el dispositivo del cuerpo abyecto cumplirá una función estético-política en la novela: profundizar la fuga más allá del cogito cartesiano y colonial, más allá del sujeto logo y falogocéntrico. El movimiento antropofágico de las vanguardias brasileras constituiría un importante antecedente de este quehacer en 1928. Sin embargo, aquí el canibalismo no solo afecta la crisis de lo 
nacional globalizado. Sostengo que se trataría más bien de una antropofagia patriarcal ${ }^{6}$.

En Chile, donde la separación entre Iglesia y Estado ha sido cíclica e incompleta, particularmente a partir de la dictadura y sus secuelas, la visión laica de las relaciones entre cuerpo, sexualidad y cultura ha sido un proyecto en difícil construcción. Mientras más fuerte resuenan la represión y la censura, más fuerte emergen la repugnancia y la indignación ante la violencia material y simbólica de los cuerpos. Hacia el final de la novela, la protagonista narradora se separa de Sergio, relación marcada por el engaño y la mansedumbre, marcando el deslinde de la hegemónica "correspondencia absoluta entre sus cuerpos y sus mentes" (175). La insumisión es una forma de contraviolencia, una representación que encierra la abyección como resemantización de los opuestos excluyentes entre otro y otra. El abyecto marca el polo de la revuelta, allí donde extrañeza y repugnancia emergen en el límite entre la castración y la alucinación (Kristeva 1988, 8). A partir del canibalismo escritural, la contraviolencia expresará sobre todo la desconfianza que le suscitan las relaciones asimétricas (Amo/amor): "Alucinaba finos cortes que atravesaban la carne" (50); "Necesitaba equiparar la violencia" (60). Vaca Sagrada se convierte en la entrada estético-literaria a ese linde de lo abyecto y la abyección en una sociedad que se mueve entre la represión y el deseo edípico, entre el asalto mercantil, la razón y el ideologema del espectáculo. Provocar una vuelta de tuerca y transformar lo abyecto en valor estético funciona a modo de esbozo de los límites de esta novela, escribir desde "márgenes intrusos" (87).

La "rotura" entre mente, lenguaje y cuerpo se convertirá en el horizonte semiótico de gran parte de las escrituras chilenas, sobre todo a partir de la década del 80. El tiempo de los "cuerpos ingrávidos" se habrá dispersado (Eduardo Barrios) para emerger con una materialidad sensorial al borde del sinsentido - textura que asalta, desconcierta y deslumbra a la vez, particularmente en los textos de Diamela Eltit. La densidad figurativa se condensa al borde de la comunicabilidad e irrumpe con violencia semiótica en la superficie del texto, recordándonos letra a letra que el cuerpo pulsa en las propias

\footnotetext{
El canibalismo cultural brasilero apuntaba a una capa profunda y desconocida; retomar estéticamente ese Brasil subyacente, embrionario, implicaba realizar una síntesis cultural autónoma, con mayor densidad de conciencia nacional (Andrade 1975). "Manifesto Antropófago", Revista de Antropofagia. São Paulo: abril.
} 
escrituras, al bies del registro simbólico de la cultura; que su régimen no es de los compartimentos estancos y el canibalismo simbólico será la contra violencia. Hoy la letra encarnada es nudo feminista y cuir, sobre todo a nivel de los dispositivos de poder que encarnan en las subjetividades. Las violencias se han acumulado, abriendo brechas insondables en el cuerpo de la nación y en los cuerpos sometidos a extremos actos de violación, secuestro, tortura, muerte. Violencia simbólica, violencia sexual y agonía moral despuntan perturbadoramente en nuestra literatura. No es que no las hubiera antes, en los años 20 o en los 30, en los 40 o en los 60. Es que las violencias siempre parecen recién paridas en su inmediatez histórica y biográfica, en su seco impacto, desde la calle a la madriguera de lo doméstico. Los 70 y 80 nos sacudieron generacionalmente con una fuerza solo equiparable tal vez a la intensidad de esa utopía creíble que se alzó en los años 60 y 70, pero también en relación con los subsiguientes golpes de impunidad y olvido en dictadura y postdictadura: "me había correspondido habitar en un espacio sin historia, un territorio infértil, un acoso brutal" (79).

\section{SUBJETIVIDADES ENCARNADAS: HABITAR ES LA CONSIGNA}

¿Cómo se apropia Vaca Sagrada del cuerpo? ¿Cómo suenan el cuerpo y la piel, el golpe seco del insulto o la herida abierta del ojo en esta novela? Para este estudio, invirtiendo el "sentido común", entendemos lo obsceno precisamente como desmemoria -tatuaje de un sistema de poder cuyas estrategias han situado y sitiado la subjetividad en una brecha excluyente entre lenguaje, mente y cuerpo. Ante esa estrategia de blanqueo, Vaca Sagrada hace proliferar el tinte de la sangre, verdadero hilo de la trama novelesca. El cuerpo se ha convertido en soporte de la vida y al mismo tiempo en el mayor objeto de abyección, frontera móvil entre la vida y la muerte, fantasma del propio cadáver de lo humano, asalto a la racionalidad vigente. La sangre, semantema de la novela, es hilo que fluye entre esas fronteras; perra sangrienta, cuerpo que muge.

Para "cuerpos insignificantes" (170) como los de las mujeres golpeadas, las prostitutas, las trabajadoras maltratadas de esta novela, ¿es la violencia muda? Su sinsentido ¿es del todo expresable más allá de sonidos guturales, chispazos de imágenes en desorden, sintaxis violentada? ¿Cuán referenciable es el "extremo nomadismo interno" que sacude a los cuerpos vejados, despojados sobre todo de su propia subjetividad? (70) ¿A qué dispositivos retóricos refiere esta violencia epistémica? En algún momento de la historia occidental, la 
des-subjetivación pasa a primer plano con la naturalización del cuerpo, al menos en dos pliegues epistemológicos: a) en el neopositivismo de la ciencia y b) en los esencialismos filosóficos. En la larga trayectoria del patriarcado occidental, la des-subjetivación afecta a las mujeres y a los subalternos, ubicadas/os en el ámbito de lo natural, supuestamente más cercanas/os a lo animal que a la cultura, a la barbarie más que a la civilización letrada. Hoy, esta mirada a Vaca Sagrada, puede contribuir a reubicar el sexo en una cultura de cuerpos subjetivados en sus diferencias equivalentes.

No se trata aquí de naturalizar la subjetividad, sino de encarnarla y poner en debate tanto la naturalización como la des-naturalización de esa materialidad heteróclita, carne de relaciones inter e intra subjetivas en el campo de la cultura: "Mi ávido animal quiere pastar...no tengo animal" (168). Asumir la desvalorización de ciertos sujetos, sobre todo femeninos, es sinónimo aquí de un cierto devenir animal, pero no se trata simplemente de asumir la metáfora de "vacas sagradas", porque ello conlleva constructos de biopoder en los que se ha mitificado su potencial de reproducción, su sexuación subalterna, su mansedumbre. Vaca Sagrada pasa de lo reproductivo a la creación estética para asumir identidades plurales que se van conjugando en dialéctica performativa, entre el cuerpo y la subjetividad en territorios cada vez más urbanos: "Una infección la tenía fuera de sí, agravada por la ciudad, por los pedazos de ciudad pegados en su cuerpo. La ciudad entera tenía un virus helado que deambulaba por dentro de los habitantes" (159).

Mi relectura del texto de Diamela Eltit parte del dilema de un cuerpo en estado de "extremo nomadismo", "fracturado" e "irregular" (70 y 126, respectivamente), cuyos efectos escriturales producen el "desbande de los signos" (44). Escrita en primera persona, la novela supone un "destino reflexivo", abierto a la intimidad y un "destino transitivo", más propio de la dimensión institucional de la escritura (Morales 2009, 144). El destino transitivo quedará subordinado a la dimensión reflexiva en la segunda parte de la novela, cuando el texto se precipita hacia una abierta puesta en abismo (escritura dentro de la escritura, segmento, "Diez Noches con Francisca Lombardo"). Entonces, la narración inscribe sus propios orígenes, desde el enunciado, "sueño, miento mucho" (11) del comienzo, al enunciado, "escribiría sobre ellos" del final (188).

La novela parodia las tecnologías de Yo y profundiza aspectos psico-sociales del patriarcado colonial respecto a las identidades y relaciones de sexo y género. Al hacerlo, erosiona formas de expresión y formas de constitución de identidades, formas de vínculo y ligazones simbólicas autoritarias, mostrando 
que (como en gran parte de la obra de Diamela Eltit) el despotismo no era solo un asunto dictatorial vinculado al registro de lo público. La ciudad letrada se hallaba ya en picada y la escritura en desbande. Aquí las violencias recorren la enunciación desde lo íntimo y privado hasta lo público y urbano. Lo corporal parece difícilmente contenido por las palabras, estando dislocada la relación hegemónica entre sexo-cuerpo, lenguaje y poder. Hacia el final, el texto así lo explicita: "pude enterarme del dilema de los cuerpos, entender la magnífica y dolorosa expiación de lo humano" (176). La comprensión del dilema cuerpo condensa la metonimia de la novela y es potenciada por el "vuelo" de los signos, por una escritura desbandada que despliega toda su empatía a partir de esa fuga.

\section{EJES DE LECTURA: DOS TRÁFICOS CORPORALES}

Esta lectura se abre primero al eje conformado por la triangulación poli-amorosa de las relaciones entre Francisca, Ana y Sergio, creciente crisis de sentido que desemboca en separación y pone en jaque a la familia monogámica y sus inocuas transgresiones; segundo, atisbamos un proceso de lenta demanda del cuerpo de Francisca en medio del despojo hacia la mitad de la novela, cuando percibe que su carne se desborda y su piel empieza a traicionarla (90). Es entonces que se logra expresar una demanda territorial de intenso sentido epocal, interseccional, de género y clase: desterritorializar el cuerpo para que "habite con soltura" (126), porque "estaban barriendo con las trabajadoras" (168). Efectivamente, una de ellas resulta ser precisamente la trabajadora escritural, en el despliegue mismo del "asalariado oficio de (su) mano" (161), referencia relacionada con la dimensión institucional de la literatura en la filiación mano/sexo, escritora/prostitutas. La mano deseante que escribe es mano alquilada. Las otras son las trabajadoras sexuales, genitales en arriendo. El concepto de prostitución se desexualiza en la medida en que se amplía a la mercantilización. Cada una alquila o vende fragmentos corporales distintos. Entre ambas se alza el terreno común del hacinamiento y los tatuajes de asalariadas: "No había nada para nosotros en la ciudad -desposeídos, vagábamos...persiguiendo un trabajo inexistente" (128). La identificación entre trabajo escritural y trabajo sexual se insinúa en la "estrechez" de los cuerpos, en las problemáticas formas de habitarlo, particularmente en la ciudad: “¿Cómo viviremos si nuestros cuerpos chocan contra las paredes? (132), "habitar fue la consigna" (133). 
La crítica Cecilia Ojeda asocia la modalidad escritural de Vaca Sagrada al desencanto con los macrorrelatos liberadores, refiriendo a la Revolución en Libertad de Eduardo Frei Montalva ${ }^{7}$. A su vez, la violencia sexual -aquella "batalla genital" de la que menos se ha hablado institucional, estéticamentese devela como evento indecible, verdadero blanco en la memoria de subjetividades singulares y colectivas (60) en el plano de la enunciación. La violencia es el límite. Sangramientos genitales y oculares expresan múltiples espacios y lugares del poder, cuyas relaciones emergen ubicuas y fluidas entre lo íntimo y lo público. Traspasar esa situación-límite en los propios dominios de la lengua, he ahí la cuestión. Habitar la violencia física ("golpes de puño cerrado") y la violencia verbal ("perra malagradecida"), dar sentido a los "extremos marginales de su cuerpo" (70), se constituyen como encrucijadas escriturales de esta novela, en la que por instantes se aspira a "gruñir como un animal" (104) o poner en palabras toda la "agonía moral" (175) de nuestros tiempos. En ese contexto, Vaca Sagrada inaugura una vocación por dar forma estético-política a violencias que para los años 90 emergen con signos plurales y abarcando espacios heterogéneos. Me refiero a concepciones de poder que han dejado de centrarse en lo palaciego para adentrarse en los pliegues de lo corporal y sus partes: femicidios, violencias en las madrigueras domésticas, la "garra dulce" de lo erótico, la extracción corpórea y genital del lucro. Todo ello, contra el vestigio semi-oculto de los diecisiete años de torturas y prácticas de patíbulo "no convencional". Se trata en mi opinión, de una labor no menor sobre todo al comienzo de la postdictadura, cuando el Informe Rettig se estaba gestando y las deudas históricas estallaban en la superficie lisa de lo innombrado e impune ${ }^{8}$. Lo realmente obsceno y abyecto se ha desplazado al escenario nacional pos

\footnotetext{
Ojeda, Cecilia (2). Si bien hay más de alguna similitud entre la Revolución en Libertad de Eduardo Frei y el proyecto de la Unidad Popular de Salvador Allende, las diferencias son notables; el Golpe Militar se dio contra ese último y con el apoyo explícito de la directiva del Partido Demócrata Cristiano.

La Comisión Nacional de Verdad y Reconciliación fue un organismo creado en Chile por el presidente Patricio Aylwin en 1990, con el objeto de esclarecer "la verdad sobre las graves violaciones a los derechos humanos cometidas en el país entre el 11 de septiembre de 1973 y el 11 de marzo de 1990", periodo que duró el régimen militar de Augusto Pinochet. La comisión fue presidida por el jurista Raúl Rettig. Su resultado se conoce como Informe Rettig. El 8 de febrero de 1991, la comisión entregó al presidente Patricio Aylwin un informe final en que se detallan 3550 denuncias de violaciones a los derechos humanos, de las cuales 2296 fueron consideradas como homicidios calificados.
} 
dictatorial, aquí cuando a más de cuarenta años de la dictadura, la impunidad se ha impuesto como límite de "realismo posible" entre la democracia y la justicia histórica, particularmente respecto a violaciones sexuales cometidas en el contexto del terrorismo estatal.

En la novela, la repolitización de los "entres" (cuerpo/cultura) se torna más inquietante que nunca. Las esencias separadas son constructos del lenguaje, no del mundo ni de los cuerpos (Merleau Ponty 1993, 15). Por eso, lo que aquí ha entrado en ruptura no es meramente un tipo de cuerpo ni de discurso. Más que el binarismo propiamente tal, se trata de una cierta lógica excluyente con la cual se conjugan los binarismos; un tipo de relación entre lo existente y lo visto, pensado o representado, el propio nexo de los binarismos. El cuerpo aún se expresa desde el binarismo abstracto $(O-O)$ : o cuerpo visto o cuerpo viviente. Sin embargo, Vaca Sagrada muestra que la propia relación es sistémica; sistema-mundo, sistema-cuerpo, sistemadiscurso. Sistema de resonancias hegemónicas. El nexo es carne política, carne biopolítica. La novela conjuga cuerpo visto $y$ cuerpo existente, cuerpo golpeado (Francisca), cuerpo desaparecido de la intriga (Manuel, torturado en el sur), cuerpo alquilado (prostitutas y escritora). La acumulación es el propio significante de las coordenadas de un poder corporeizado: un biopoder. La encarnación narrativa se constituye en provocación directa a la ley, aquí donde la violencia ha sabido condensar el malestar en el seno del sistema binario predominante. La ideología hace carne en sujetos y objetos reificados, en la propia materia de estas corporalidades sobrantes abiertas por la novela. El mundo es menos lo que pienso, que lo que vivo; el "propio cuerpo está en el mundo como el corazón en el organismo: mantiene continuamente en vida el espectáculo visible, lo anima y lo alimenta interiormente, forma con él un sistema" (Merleau-Ponty 1993: 219). La comunicación con el mundo privilegia el "piel a piel"; un "cuerpo a cuerpo".

En este sentido, Diamela Eltit se juega a la posibilidad de trastocar la relación cuerpo/cultura vigente, planteando que se vive en un universo de experiencias, en intercambio directo con los seres y las cosas, con y desde el propio cuerpo para-sí y para-otros, desde el sistema de percepción y las representaciones. Es de ese trecho que se trata: entre la primera y la segunda piel (Anzieu 1998, 51), entre la invisibilización del poder y el tatuaje de la carne, entre las violencias urbanas y la violación sexual, entre lo privado y lo público, la vida y la muerte, la producción deseante y el hábito, la mansedumbre y las fugas libertarias. Exorcizar a la mansa, dócil vaca sagrada, significante de lo femenino en tanto reproducción de la especie, pero también 
deconstruir la fuerza de trabajo y los ideologemas del capitalismo patriarcal, ahí la semántica textual.

Para las subjetividades, la experiencia de la violencia resulta más próxima a lo carnal que a lo conceptual; ella pone de relieve algo que estaba ahí todo el tiempo. El cuerpo viviente parece inenarrable, aunque es obstinadamente narrado aquí. En el dolor, la lengua resuena. Se vuelve sonido. Por eso el desafío del taller de significación de Vaca sagrada es doble: no ceder al silencio ni a la autocensura; configurar el territorio corporal en una nueva economía estético-política. " $Y-Y-Y$ " en lugar del estamental y rígido “ $O-O-O$ ”. Resistir es del orden del sentido $Y$ del cuerpo. No hay mayor desmesura; la narradora no sabría morderse la lengua (93). Todo comienza y termina aquí con la sangre; con sus flujos y cortes, con sus nuevos engarces, en devenir incierto.

Los feminismos han puesto en evidencia la importancia de introducir el cuerpo sexuado en las definiciones de subjetividad y cultura (Irigaray 56). En Vaca Sagrada se narra la emergencia de un sujeto femenino en crisis, ajeno y culpable a la vez (Eltit 1991). Pero ello no puede narrarse como Bildungsroman, en la medida en que los ciclos no inscriben el acceso a la razón patriarcal sino que recorren el hilo de la sangre, desnaturalizando ese orden a partir de la desmesura escritural. Más que el aprendizaje consciente del sujeto, el ciclo textualizado por la novela narra el descenso al cuerpo, a la tesura de la carne, apertura a una memoria oculta para la propia protagonista en la medida en que ella ha sido des-subjetivada por el amor y por el establishment letrado, por el trabajo enajenado y por la territorialidad urbana.

El imaginario urbano de las trastierras latinoamericanas en el hipercapitalismo condensa esa desmesura en sus propios e impropios desplazamientos, situándose a medio camino entre el discurso letrado y el cambiante sistema de percepción, en una relación específica entre el sistema mundo y el sistema cuerpo, entre soma y sema. La apertura de la novela a la subjetivación de la protagonista tensiona y reposiciona binarismos como lo interno y lo externo, el yo y los (as) otros (as), el cuerpo y la palabra, la oralidad y la escritura, lo femenino y lo masculino, la naturaleza y la cultura, lo "sano" y lo "malsano". El deslinde entre lo privado y lo público es siempre zona de infección, dice el verbo lúcido de Francesca Lombardo (Lombardo 1998). La letra, ilustrada y sobre racionalizada, minoritaria en el vasto horizonte de las parias, no puede contener ya este "desorden". No puede inscribir lo humanamente desconcertante. Tampoco la "miseria exhibicionista del dolor" (174).

El cuerpo fragmentado y múltiple, turbulento y problemático, en estado performativo y móvil, emerge como zona de inquietud y asombro precisamente 
en virtud de la coagulación de la representación: "mi corazón estaba congelado" (187), dice hacia el final de Vaca Sagrada la protagonista narradora. La esencia de los binarismos excluyentes separa y coarta la turbulencia del devenir encarnado. El sujeto encarnado no solo está en el mundo. Habita en flujo ${ }^{9}$. Máquina de pulsiones y acontecimientos fugaces que la estrechez del territorio no abarca. La tensión entre "coagulación" y "flujo", entre cuerpo visto y cuerpo existente es sin duda estéticamente productiva para aproximarnos a la textura de Diamela Eltit, en particular a partir de la figura de la sangre y sus flujos. En contraste, la cultura letrada privilegia el ojo-panóptico que no solo lee en nombre de todos, sino que al hacerlo segrega en nombre de unos pocos. Sangre en el ojo, la protagonista escribe y concluye finalmente que "brotaba sangre por todos los orificios del cuerpo" (161), proliferación desmedida de la vida, fuga hacia la diferencia, viraje hacia sordas batallas de sentido. Las de-subjetivadas sabrán acceder al discurso a su propia maniera. La complicidad de la puesta en abismo escritural así lo denuncia y enuncia.

\section{LA GENTE QUE SANGRA NO ENGENDRA}

Ya antes, Diamela Eltit había anticipado el dilema del cuerpo y el flujo en la escritura: "Está dicho/Sangra" (Eltit 1991, 174). La autorreflexión la lleva a concluir que la propia demanda escritural habría venido de su sangre (187), de su sexualidad, de entre sus piernas, aquella "más preciada mercancía...por donde se me iba la vida" (187). Vaca Sagrada fluye por y con la sangre desde los bordes de lo biológico a lo cultural y viceversa: erotismo, sexo mercantil, memoria, violencias, escritura. En el caso de la novela, a lo marginal se suma la figura preponderante de la sangre, flujo que posibilita el desplazamiento metonímico de la novela desde el inicio narrativo y que como bien han señalado otros críticos, se vincula semánticamente a lo femenino a partir de la menstruación. La significación semántica y semiótica de la sangre se extiende a dos dimensiones más: la violencia sexual, de género y la devaluación de

\footnotetext{
El sujeto del cogito cartesiano es universal y abstracto. La noción de sujeto performativo y encarnado remite a dos aspectos: a) que el sujeto se "actualiza" en su devenir, concepto de origen chomskiano, que no está previamente definido ni predeterminado, y b) que el sujeto se hace "carne" en cuerpos sexuados, los que a su vez, son directamente intervenidos por dispositivos de poder en el régimen del patíbulo, en el encierro, el castigo, el panóptico, la prisión o la medicalización (Foucault 1986).
} 
las "otras" especies por parte de una cultura que segrega lo animal como expresión devaluada de la otredad y la diferencia, de la corporeidad y de lo no androcéntrico. La novela transforma el aforismo de Bataille, "en cada hombre un animal encerrado en una prisión", en fuga libertaria: "mi animal escondido salió de su guarida" (96). El tránsito novelesco es, a partir de la asociación con lo corporal y animal, un "descenso" (96). Al inicio, la protagonista ve sangrar a una perra parturienta que arrastra la barriga, "dejando destilar un hilo de sangre" (44) y esa visión, como un corte en primerísimo plano, abre el descenso hacia lo inesperado. La panza reproductiva está abierta. La sangre marcará los ciclos de la novela (íncipit, conflictos, desenlace) en son de la sexuación, diferenciación equivalente, individuación femenina: menarquía, menstruación y menopausia. Estar o no estar con sangre determinan goce y castigo, sexualidad o apetencia, mentira o conocimiento, pero también violencias y posibilidades de autonomía.

El yo deviene una tecnología particular de sexuación, de individuación sexuada y corporalidad abierta, pero, paradójicamente, lo sexual es a su vez una estrategia des-territorial, actancial y subalterna, que tiene en esta novela como lugar privilegiado a los sujetos de triangulación amorosa -ya sea en el erotismo orgiástico o en la asfixiante mansedumbre, en la reificación de la mercancía, en el delirio alucinatorio o en el maltrato cotidiano. Entonces, la subversión se expresa en la turgencia de traspasar a otra especie, a otro estado animal: perra o pájaro, cucaracha, cordera o vaca. La otredad no parece reconocer fronteras. Sin embargo, advierte la novela, el límite radica en no ceder al exhibicionismo del dolor ni a la "monotonía de un cuerpo incesantemente profanado" (Eltit 1991). Tampoco ceder a la victimización, orgía hiriente de un prolongado "asedio genital" (Eltit 1991). La diferencia con Sade es fecunda: de la improductividad reproductiva a la creación estéticopolítica, la ruptura de vínculos y la plena soberanía producen violencia y goce, sangre y flujos deseantes, pero sobre todo autonomía, "la gran soledad de un ser verdaderamente libre" (Bataille 54) que escribe.

La novela habita los sitios de lo abyecto para experimentarlo, conocerlo, narrarlo, criticarlo. Para ir más allá de él. La autonomía se va conjugando en el seno del reticulado político y económico de la familia nuclear, del dinero y de su ley-verdaderos agentes del dolor: "Mi cuerpo desnudo alcanzó una autonomía sorprendente, asalariada, encabritada" (96). De ahí el trabajo estético con la profanación animal y sexual. La escritura profana lo "sagrado" de la vaca. Lo torcido, agonía moral, se desprende de esas mismas instituciones, escenarios del asedio corporal que luego se expresa como "moralina" victoriana 
(Monsiváis 1999, pp. 46-48). Vaca Sagrada pone en relación la sexualidad (en tanto abuso y tortura, goce y dolor) con la dictadura y la postdictadura, pero sobre todo en tanto regímenes vistos del revés, desde lo cotidiano e íntimo, politizables estéticamente.

La crisis de la sujeto en relación con el lenguaje va produciendo varios desmoronamientos en la hegemónica construcción del sistema cuerpo/discurso. Ya Lumpérica en 1983, había enunciado la enajenación por "la pendiente de la letra" (Eltit 1983, 105). En los mapas periféricos, el cuerpo de las mujeres -útil en el Sistema Sexo Género hegemónico, solo en la medida en que se niega como ser-para-sí- remite en última instancia a otro espacio, a una productividad otra. El deber-ser escritural se construye a contraluz de la agonía moral existente para que los cuerpos de ellas dejen efectivamente de ser insignificantes (174). La escritura de Eltit -no solo Vaca Sagrada-inscribe a la sujeto escritora en el malestar del establishment literario y de la institución mercantil del discurso ("condición asalariada de mi mano"). Entre la mano asalariada y la "enorme lengua rosada" (181), una civilización deseada y diversa, pero aún en suspenso. La metáfora del cuerpo prostibulario y abyecto condensa el vínculo entre nación y sexo/género; redibuja las homologías entre política sexuada y política excluyente aquí, en la nación periférica. La letra ya está en la pendiente, degradada y violentada "desde abajo", desde el hilillo de la sangre. El Yo es subjetivable en la medida en que niegue la cordera y la mansedumbre de la vaca: "era la cordera, no era yo, entre la cordera y el animal que mugía" (96). Esa gradiente es un descenso hacia la abertura de lo "inferior", hacia el animal y la genitalidad, hacia la perra y la sangre que "llegaba todos los meses" (44) para descender hacia la discontinuidad entre el abajo y el arriba, la inversión de rangos y jerarquías: "Mi animal... mugía por salir con una enorme lengua rosada" (181). La correspondencia entre cuerpo y mente se ha conjurado de otro modo. Puede que cuerpos como ésos no engendren ni procreen, pero indudablemente crean.

\section{NEOBARROSA DIVISIÓN SEXUAL}

A su vez, la corporización estética de los fragmentos "desechables" de nuestra historia inmediata no solo remite a lo "neobarroco" o neo vanguardista, sobre todo si esas categorías se esencializan. Vaca Sagrada comparte con aquellas estéticas el paisaje dislocado de planos y oraciones, la predilección por lo asimétrico, las distorsiones y contorsiones sintácticas, la continuidad de la vida y la muerte (la sangre), la fusión de lo ficticio y lo real. La distinción 
misma se hace borrosa o barrosa si no contextualizamos la enunciación en sus coordenadas específicas.

Me resulta enriquecedor el giro paródico de Néstor Perlongher (1949-1992) al acuñar el término "neobarroso", para aproximar el concepto de neobarroco al fango rioplatense y, por extensión, a nuestras trastierras periféricas en un gesto de autonomía identitaria ${ }^{10}$. Que la sangre, ese "fango" cultural, emerja a la superficie de la literatura, la ciudad letrada y la historia, he ahí el mandato feminista y cuir de Vaca Sagrada.

En un plano genealógico, la constitución de la masculinidad hegemónica, en su supuesta oposición absoluta a lo femenino, sostiene una relación ambivalente hacia la sangre, principio de diferenciación de la mujer vista desde abajo, desde la genitalidad. En el patriarcado, la construcción simbólica de la sangre y sus ciclos determina la subordinación de la mujer al útero y a su capacidad de "reproducir", aunque para el goce masculino, esa dimensión pueda ser suspendida, fingida o censurada. La protagonista de la novela debe "fingir" no estar en sangre, de lo contrario Sergio no la acepta para el goce. Cuando el hábito de la convivencia termina con su deseo, es Francisca quien finge. La mentira vincula erotismo y escritura.

Culturalmente, el útero y la procreación aparecen agigantados para la mujer, en la misma medida en que su deseo y creatividad aparecen invisibilizados. El destino no es la anatomía, sino el biopoder: "Volved hacia fuera [los órganos genitales] de la mujer, doblad y replegad hace adentro por así decirlo, los del hombre, y los encontraréis semejantes en todos los aspectos" (Lacqueur 55). La mujer (y por extensión, lo femenino o afeminado) ha sido construida como lo "invertido" en el imaginario científico del siglo XVIII. El esperma (lo masculino) engendra. La sangre (lo femenino) no, diría con mucha antelación, Aristóteles. Lo femenino solo se engendraría a sí mismo. Lo masculino sería único "poseedor del principio de movimiento y generación" (Aristóteles 1994, 63). La genealogía heterotópica de la sangre deviene metonimia de lo invertido y subalterno desde muy atrás. La lenta duración de la ideología patriarcal sobre el cuerpo supone que mientras uno aporta el movimiento y la forma (elemento activo), la otra aporta supuestamente la

10 No es posible profundizar sobre las relecturas y lecturas críticas en torno al neobarroco en este ensayo. Concuerdo con Perlongher y Soledad Bianchi al enfatizar la parodia en el concepto de "barroso" aplicado al neobarroco. Ver su texto en El Barroco fronterizo, número temático de La Revista Chilena de Literatura. 
materia y el habitáculo del "embrión", convirtiéndose en ideologema de lo pasivo. Luego, en tanto "madre", la mujer no habrá sido representada para conocer ni gozar ${ }^{11}$. En última instancia, las inversiones de la novela a nivel de la enunciación se relacionan con la transformación de la reproducción en producción deseante (creación estético-literaria), aún después del "fin" de la sangre. La novela sí puede decir la sangre y la ausencia de ella, aunque para eso deba destronar el ideologema ilustrado, romper con las filiaciones patriarcales y hacer estallar el Edipo en la relación tríadica entre la protagonista, Sergio y Francisca. Irónicamente, la autarquía y la ausencia de sangre de la protagonista marcan la conclusión narrativa. El estallido final de la novela habrá sido un fin, no un medio.

\section{PICOTEO DE PÁJARO. BUM, BUM}

Al comienzo de la novela, el ojo coagulador está ya destruido; viene astillado desde antes: "una estaca...venía a mi ojo derecho para cegarme, se desviaba y...se incrustaba entre mis piernas abiertas" (97). Mirada existente o cuerpo visto, el cuerpo vivido y la mirada táctil, se privilegiarán por sobre el ojo ilustrado y panóptico, ojo que lee y ojo que vigila, respectivamente. No ser la mujer mirada. Ingresar al esquivo universo del voyeurismo. Mujer mirona y deseante. En este punto del texto, el ojo panóptico se derrama, Disperso por todo el texto, el ojo es perforación ocular, carne abierta. Sin el ojo roto, no habría exterioridad posible; solo agujeros negros y superficie agujereada. Aquí emergen fragmentos corporales parciales, sin la "redondez" del rostro visto desde el ojo, sin la contención del espejismo de cuerpo total, redondo, unitario y entero. Por los orificios se adentra el placer, cuando la sangre ha devenido neutra (176), hecho que ocurre cuando la prostituta asume su alquiler sexual: "mi paga servirá para ir matando fríamente a mi animal" (100); "no me voy a contratar por un salario de hambre" (109). La especie animal entra en contradicción excluyente con la especie mujer y con la especie trabajadora sexuada; solo aflorará semánticamente en el relato a partir de desplazamientos insumisos.

11 Lacqueur muestra que durante dos siglos la ciencia sexual supuso la ausencia del orgasmo femenino, dado que no se requería orgasmo para la procreación (Lacqueur). 
La relación entre la novela y el corte de ojo ha sido comparada con el inicio de El perro andaluz y marca la diseminación de otros cortes y engarces en los enunciados novelescos. Ahí las máquinas deseantes. Por eso, la mejor aproximación a esta retórica es un imaginario en movimiento. Sin corte, no hay flujo. La triangulación, Ojo/Lenguaje/Humanismo androcéntrico, está colapsada. Los lazos entre ojo y violencia se hacen evidentes en el golpe, "puño cerrado en uno de sus ojos" (73). Luego, la asociación de la violencia se acopla a la dupla en el semantema "ojo/pájaro". La narradora observaba esa dupla "atacar el cielo con sus alas" (181). Una ambigua ligazón entre pájaro, ojo y violencia se anuda en el pájaro negro que le vuela un ojo, en la "bandada" de pájaros que se deja caer sobre la carne de Manuel. Una "multitud de horribles graznidos" (60) va anunciando la entrada del odio a la intriga narrativa; la propia agonía de la narradora deviene una bandada que oscurecía el cielo en la tarde. La figura ambigua y ambivalente del pájaro enuncia referencias al autoritarismo y al logocentrismo en relación con los cuerpos, a los sujetos sexuados, al territorio. Se anuncia una desarticulación epistémica, estética y política que la escritura de Diamela Eltit ha sabido desplegar con fulgor en toda su obra.

¿Cómo se conjuga la triangulación Ojo/Lenguaje/Humanismo androcéntrico? La novela parte con un rotundo quiebre en el horizonte de las filiaciones (la abuela estaba muriendo al comienzo del relato), en el registro de los amores (Manuel está preso en el sur), en las relaciones de la literatura chilena con la "poesía lárica" (el semantema del pájaro de "mal agüero", su vuelo y sus bandadas). Son rupturas que hablan de cortes genealógicos con la función supuestamente idílica de la infancia y el terruño de la poesía lárica. El sur ha devenido lugar de violencia política en el caso de Manuel. Ya no hay vuelo de ángeles ni de gorriones, parafraseando intencionadamente a Jorge Teillier ${ }^{12}$. La

12 Aquí solo refiero a la llamada "poesía lárica" del sur y a las "alas del paraíso" en contraste con el picoteo del ave de carroña. Obviamente, esto no es extensivo a toda la escritura del sur, como se entiende si estudiamos texturas de Marta Brunet (Oyarzún 2014). Jorge Teillier (1935-1996), impulsor de la llamada “poesía lárica”, es parte de la heterogénea generación de poetas nacidos alrededor de 1930 junto a disímiles proyectos escriturales de Enrique Lihn, Miguel Arteche o Armando Uribe. Cito: "Frente al caos de la existencia social y ciudadana los poetas de los lares (sin ponerse de acuerdo entre ellos) pretenden afirmarse en un mundo bien hecho, sobre todo en el mundo del orden inmemorial de las aldeas y de los campos, en donde siempre se produce la misma segura rotación de las siembras y cosechas, de sepultación y resurrección, tan similares a la gestación de los dioses [...] y de los poemas", 
indeterminación del ojo/pájaro, esa "golosina caníbal"13, avanza. La narradora imagina una "bandada alejándose con la carroña atrapada entre sus picos" (69). Sabemos que la palabra "pico" en Chile refiere a falo. Corte urbano con la nostalgia, la tierra ancestral y el paisaje rural. El "vuelo poético" ha descendido al registro animal, a la "bajeza" del cuerpo, a chirridos y graznidos perturbadores. No hay aquí origen ni destino mítico. El ideologema del mito ha eclosionado. Ni relaciones de supuesta armonía, ni naturaleza prístina a la cual referir. La violencia ha caído en bandada sobre el lírico sur lárico, relegado a territorio sitiado. La extrañeza ha sustituido la relación entre ojo, palabra poética y espacio. La narradora ve a los pájaros cruzando el cielo en su "orden despótico"; los observa "atacar el cielo con sus alas" (181).

Una vez vinculado el pájaro con la violencia, "bum, bum” (168), resonancia de castración y agonía en la novela, se produce el vuelco abyecto; la asociación entre pájaro, erotismo, placer y canto: "cantaban al cielo", "chillaban sin saber yo desde qué júbilo", "graznidos de placer", de "un placer gutural y salvaje que avergonzaba lo humano", "sordidez diseminada en el canto" (182). Los pájaros "harían cualquier cosa por sobrevivir y por eso el canto, y por eso la atrocidad primitiva que los habitaba" (182). La lenta y tortuosa castración patriarcal va configurando un "vuelo fatídico de pájaros" (183) en cuyo "orden despótico" resuenan el patriarcado y la prolongada agonía moral del sistema dictatorial pactado que merodea la enunciación novelesca. La figura del pájaro es también metonímica. En uno de esos pliegues, el relato logra condensar la figura como desplazamiento fálico, "erecto" de un "pájaro enardecido", un "maldito pájaro desconsiderado" (93). La narradora lo interpela hacia la mitad de la novela: "no te creo nada. El pájaro ciego y sordo sólo se levanta al ritmo de su apetencia, pájaro adulador y mentiroso, estás con el pájaro en la mano alado en la cama y finges soñar conmigo" (93). Es éste el que irá asociando a la dimensión falogocéntrica de la escritura: "caligráfico, pájaro tramposo", "eco de un mismo éxtasis" que "se ha refugiado en la cúpula de un pájaro (113), de género ambiguo, "vieja lechuza de mal agüero" (178). Hacia el final, el falo simbólico, de fugaz aleteo (109), se descompone ante los ojos de la narradora en tanto su espejismo de placer y violencia remite al sexo/mano alquilados: "la condición asalariada de mi mano no fue oportuna

Teillier, "Los poetas", cit. Alexis Candia, "El paraíso perdido de Jorge Teillier", Revista Chilena de Literatura, Abril 2007, Número 70, 57-77.

13 Cita de Bataille a Stevenson. En: La Literatura y el Mal. 
más que para rozar a un pájaro hambriento y medio ciego que se apartó de la bandada" (181).

Puede que el desborde del cuerpo en la novela se vincule a la inquietud por la cotidianidad, al auge del feminismo y los estudios cuir, a la politización de la intimidad y la afectividad, a las cartografías urbanas, pero también a la creciente importancia y resignificación del imaginario post cinematográfico y urbano (Martínez 1996). Diamela Eltit hace aflorar las indicaciones performativas que despliegan peregrinajes y territorios, paisajes y tiempos urbanos desde Lumpérica. Ahí, la ciudad ya se convertía en desmesurada textualidad, "ciudad prostibularia del capitalismo tardío" (Bianchi 39). El contraste entre los signos urbanos y ese sur al cual se desliza la fuga imaginaria de la protagonista durante gran parte de Vaca Sagrada se disuelve en la búsqueda y hallazgo de espacio y oficio propios, en una de las habitaciones de su casa: "escribiría sobre ellos amparada en la soledad" (188). La madriguera doméstica, domos de sometimiento, habrá sido resignificada al ser reconquistada para sí en la escritura.

¿No es la abstracción del cuerpo (el cuerpo del trabajo incluido) uno de los rasgos más definitorios del fetichismo de la mercancía? En virtud de las estrategias de patíbulo de la dictadura, de la "vil y sensual" corporalidad mercantil o de la codificación virtual y digital, hoy parecemos más cerca de corporalidades heterogéneas en disputa, tal vez porque en la pos dictadura hemos presenciado más de cuarenta años de eclosión figurativa, que ha entretejido los hilos de una historia en "inexorable agonía" (178). Esa crisis se perfilaba ciertamente al comienzo del retorno de la democracia cuando fue publicada la novela. Y en estos últimos años, nada parece más evidente que esa prolongada agonía sistémica. El desencanto hacia los contratos sociales, textuales y sexuales vigentes obstaculiza con un excedente estético las viejas jerarquías, los rangos y estamentos -excedente de desilusión en el horizonte pasmado de nuestras más conservadoras modernizaciones.

El ciclo novelesco avanza hacia la resignificación del yo, hacia identidades no-yoístas: "perdí junto con la mirada mi soberbia" (183). El desmantelamiento de la descorporización neocolonial va estrechamente ligado a una auto nivelación, a un despojo liberador del yoísmo vertical. Cuerpo existente y cuerpo visto se distancian y oponen en un pliegue que, a más de ser "construido simbólicamente" y de ser sobreimpuesto con una violencia que no siempre ha sido "meramente simbólica", puede llegar a convertirse en soporte de contrapoder estético-político. Desde esa diferencia de piel (de indumentaria "carnal", se entiende), la escritura de Eltit ingresa a la arena movediza de 
los territorios de la coerción y despliega el deseo, la voluntad deslumbrante de existir de otro modo, de reinventar registros escriturales, discursivos y civilizatorios de otro tipo. La cartografía chilena de las marginalidades incluye no solo parámetros sexo-genéricos y etno-raciales, sino particularmente mnémicos. Vaca Sagrada rescata memoria y retazos biográficos fallidos. Sobre esos soportes psicofísicos se abren reconfiguraciones de cuerpos y texturas deseantes.

\section{ESCRIBIR AMPARADA EN SOLEDAD}

El fin de la novela es un comienzo, una segunda historia. El proceso narrativo se espejea reflexivamente hacia el final, cuando la protagonista enuncia que recién entonces inicia un "angustioso viaje tras (sus) propias pistas abriendo un jeroglífico por los extramuros de (su) mente" (187). Lo estético se hallará inscrito en esos jeroglíficos, en la marginalidad de esos extramuros y en sus formas inéditas de habitarlos. El panóptico se ha subordinado al micro reticulado de la organización neoliberal del poder. La antigua metáfora de la ciudad letrada saneable e higiénica se desplaza ahora a la metonimia del virus: "una infección la tenía fuera de sí, agravada por la ciudad, por los pedazos de ciudad pegados en su cuerpo" (159). En ese punto se inscribe el sintagma del SIDA como metáfora de poder, "la ciudad entera tenía un virus helado que deambulaba por dentro de los habitantes" (159). Es aquí que el texto se precipita hacia el autodespojo, descenso hacia el conocimiento coincidente con una expiación de lo humano, en tanto soberbia y mentira; elaboración de una segunda historia y la puesta en abismo de la escritura: "cuando levanté la cabeza comprendí que escribiría sobre ellos [...] amparada por la soledad" (188).

Se dice en Vaca Sagrada que la narradora protagonista "estaba tejiendo algo caótico para otorgar sentido a los extremos marginales de su cuerpo" (70). ¿Qué es eso "caótico" en la novela? Creo que el caos generador de sentido enuncia aquí el derrumbe de un sistema-cuerpo sometido al panóptico, a la racionalidad falogocéntrica, al Edipo Capital. En este sentido, el feminismo escritural contemporáneo se abre al dilema del cuerpo para replantear un 'saber de lo somático', trazas de existencia abyecta, despojada en una corporalidad excluida y marginada de la cultura, cuya mayor ironía es la de ser precisamente ideologizada desde la simbólica de lo natural (¿qué hay más naturalizado que el cuerpo, ese animal que nos habita en la cotidianidad?). 
Es probable que la sostenida sumisión del cuerpo a la representación logo y falogocéntrica en la investigación histórica occidental se relacione con su naturalización, su supuesta esencialidad, su pretendida universalidad, su "intraducible" singularidad. Los reclamos del cuerpo se empezaron a oír con fuerza a fines del siglo XIX con el cuerpo pulsional de Freud y el cuerpo danzante de Nietzsche (Oyarzún 1995). La trayectoria llegó a su ápice en los trabajos de Deleuze y Guattari y Braidotti.

El ciclo del cuerpo en esta novela de Diamela Eltit está atravesado por un corte y un descenso. Hacia la mitad del relato, sin embargo, el canibalismo y la fiesta abren al goce y al asco de la propia abyección. En adelante, la escritura se precipita hacia arriba, hacia la recuperación del torso, de la autorreflexión y del conocimiento, pero esta vez, desde el soporte de un cuerpo abierto. El corte del hilo de la sangre abre el espacio libertario de la soledad. La creación estético-política emerge como una revuelta precisamente a partir de la abyección y su negación, el poder plenamente habitar el cuerpo "con un deseo excedido, una fuerza que giraba locamente hacia múltiples direcciones" (176). Emerge con ello la escritora y una subjetividad femenina en lucidez agónica y crítica del sistema/cuerpo en la cultura hegemónica actual, un cuerpo vivenciado como cuarto propio y en libertaria soledad.

\section{BIBLIOGRAFÍA}

Andrade de, Oswaldo. "Manifesto Antropófago”. Revista de Antropofagia. São Paulo: abril, 1975. Anzieu, Didier. Funciones del Yo-piel. Madrid, España: Biblioteca Nueva, 1998.

Aristóteles. Ética nicomáquea. Ética eudemia. Acerca del alma. Barcelona: Biblioteca, Gredos, RBA, 2007.

Bataille, George. La literatura y el mal. Editorial: El Aleph, 2000.

Bianchi, Paula. "Ciudades prostibulares en dos ficciones latinoamericanas contemporáneas". Revista Artemis, Edición V (2012 agosto-diciembre): 37-46.

Bianchi, Soledad. "Del neobarrocho o la inestabilidad del taco alto (¿un neobarroco chilensis?)". Revista Chilena de Literatura 89, El Barroco fronterizo (Abril 2015): 323-333.

Brito, Eugenia. "Desde la mujer a la androginia". Pluma y Pincel 17 (1985): 42-44.

Butler, Judith. Gender Trouble: Feminism and the Subversion of Identity. New York: Routledge, 1990.

Candia, Alexis. "El paraíso perdido de Jorge Teillier", Revista Chilena de Literatura, abril 2007, Número 70, 57-77.

Carreño, Rubí. Diamela Eltit: Redes locales, redes globales. Madrid: Klaus Vervuert \& Iberoamericana, 2007. 
COMISIÓN NACIONAL DE VERDAD Y RECONCILIACIÓN (1991). Informe Rettig: Vol. 1. Santiago: Ministerio del Interior de Chile, 2004.

Garabano, Sandra. "Vaca Sagrada de Diamela Eltit: Del cuerpo femenino al cuerpo de la historia". Hispamérica, Año 25, No. 73 (1996): 121-127.

Eltit, Diamela. Vaca sagrada. Buenos Aires: Planeta, 1991.

Fischler, Claude. El (h)omnivoro. El gusto, la cocina, el cuerpo. Barcelona: Anagrama, 1995.

Foucault, Michel. Vigilar y castigar. Madrid: Siglo XXI Editores, 1986.

Guerra, Lucía. La Mujer Fragmentada: Historias de un Signo. Santiago: Cuarto Propio, 1995.

Illanes, María Angélica. Cuerpo y sangre de la política. La construcción histórica de las visitadoras sociales 1887-1940. Santiago: LOM ediciones, 2009.

Irigaray, Luce. Yo, tú, nosotras, Madrid: Cátedra, 1992.

Kristeva, Julia. Poderes de la perversión. Ensayo sobre Louis-Ferdinand Céline. Buenos Aires: Siglo XXI Editores. Título original: Pouvoirs de l’horreur. París: Éditions du Seuil, 1988.

Labanyi, Jo. Topologies of Catastrophe: Horror and Abjection in Diamela Eltit's Vaca Sagrada, Latin American Women's Writing. Ed. Anny Brooksbank Jones and Catherine Davies. Oxford: Clarendon Press, 1996.

Lagos, María Inés. Ed. “Creación y resistencia. La narrativa de Diamela Eltit, 1983-1998”. Nomadias (1998): 71-89.

Laqueur, Thomas. La construcción del sexo. Cuerpo y género desde los griegos hasta Freud. Madrid: Cátedra, 1994.

Lértora, Juan Carlos. Ed. Una Poética de Literatura Menor, La Narrativa de Diamela Eltit. Santiago: Cuarto Propio, 1993. 127-140.

Llanos, Bernardita. Ed. Letras y Proclamas. La estética literaria de Diamela Eltit. Santiago: Cuarto Propio, 2006.

Lombardo, Francesca. "Del contagio". Revista Nomadias º 3, Santiago: Universidad de Chile y Editorial Cuarto Propio, 1998.

Martínez, Luz Ángela. "La dimensión espacial en Vaca sagrada de Diamela Eltit: la urbe narrativa". Revista Chilena de Literatura (1996): 65-82.

Merleau-Ponty, Maurice Fenomenología de la percepción. Trad. Jem Cabanes. Barcelona: Planeta Argentina, 1993. Edición original, París: Gallimard, 1945.

Monsiváis, Carlos. ¿A quién le tiene que pedir perdón? México: Letras Libres, 1999.

Morales, Leonidas. "Narración y referentes en Diamela Eltit”. Revista Chilena de Literatura 51 (1997): 121-129.

"Luis Oyarzún: el diario íntimo como diario de viaje. Modernidad y cultura cotidiana chilena", Anales de Literatura Chilena, Año 10/11 (junio de 2009): 141-159.

Moreno T. Fernando. "Vaca sagrada, Goce y Transgresión”. Una Poética de Literatura Menor, La Narrativa de Diamela Eltit. Ed. Juan Carlos Lértora. Santiago: Cuarto Propio, 1993. 167-184.

Ojeda, Cecilia. "Eltit cita a Artaud: el desborde de la(s) identidade(s) en Vaca sagrada". Revista de Estudios Hispánicos 36 (2002): 311-28. 
Olea, Raquel. "El Cuerpo-Mujer. Un Recorte de Lectura en la Narrativa de Diamela Eltit". Revista Chilena de Literatura 42 (1993): 165-71.

Ortega, Julio. "Diamela Eltit y el Imaginario de la Virtualidad”. Una Poética de Literatura Menor, La Narrativa de Diamela Eltit. Juan Carlos Lértora. Santiago: Cuarto Propio, 1993. 53-82.

Ossa, Carlos. "El soberano óptico: la formación visual del poder". Revista Chilena de Literatura 89 (2015): 213-230.

Oyarzún, Kemy. "El Hilo de Ariadna”. En VV.AA., Homenaje a los 150 años del nacimiento de Friedrich Nietzsche. Santiago: Departamento de Filosofía de la Facultad de Filosofía y Humanidades de la Universidad de Chile, División de Cultura del Ministerio de Educación, 1995. Pp. 139-151.

"Literaturas heterogéneas y dialogismo genérico-sexual". Asedios a la heterogeneidad cultural. Ed. Mazzotti y Zevellos. Filadelfia: Asociación Internacional de Peruanistas, 1996. 81-100.

"La familia como ideologema: género, globalización y cultura en Chile". Revista Chilena de Humanidades 20 (2000): 115-146.

Ed. Pulsiones estéticas: Escritura de mujeres en Chile. Santiago: Cuarto Propio, 2004.

Posadas, Claudia. "Un territorio de zozobra. Entrevista con Diamela Eltit”. INTI, Revista de literatura hispánica (2002): 229-242.

Prado Traverso, Marcela. "La obra literaria de Diamela Eltit, testimonios desde la Marginalidad". Nueva Revista del Pacífico 40 (1995).

Preciado, Beatriz (2008): Testo-yonqui, Madrid, Espasa-Calpe.

Rama, Angel. La ciudad letrada. Nueva Jersey:Ediciones del Norte, 1984.

Rubin, Gayle. "El tráfico de mujeres: Notas sobre la "Economía Política" del sexo". Trad. Stella Mastrangelo. Revista Nueva Antropología, N. 30, Vol. 8, 1986: 95-145.

Serrano, José Fernando, et al. , ¿Cómo se piensa lo “queer” en América Latina? Presentación del Dossier. Iconos. Revista de Ciencias Sociales, 2011, (Sin mes) ISSN 1390-1249.

Teillier, Jorge. Para ángeles y gorriones. Santiago: Puelche, 1956.

Tompkins, Cynthia. Aporía: la Vaca sagrada de Diamela Eltit. Explicación de textos literarios, 1998-1999. 50-61.

Violi, Patrizia. El infinito singular. Valencia: Universitat de València, 1991. 